\title{
RATIFIKASI CEDAW DI MALAYSIA: KESAN MENURUT UNDANG-UNDANG DAN HUKUM SYARAK*
}

\section{Ratification of CEDAW in Malaysia: The Effect from Perspective of Law and Hukm Syara}

\author{
Fadilla Shaharom \\ B.ShL Final Year Student, Department of Shariah and Law, \\ Academy of Islamic Studies, \\ University of Malaya, 50603 Kuala Lumpur. \\ shaharomfadilla@gmail.com \\ Mahamatayuding Samah \\ Senior Lecturer, Department of Shariah and Law, \\ Academy of Islamic Studies, \\ University of Malaya, 50603 Kuala Lumpur. \\ mahyudin@um.edu.my
}

\begin{abstract}
Malaysia has begun to ratify the Convention on the Elimination of all Forms of Discrimination Against Women (CEDAW) in 1995. The study focused on the impact of the changes found in Malaysia after the application of this convention. This study focused on the formulation, amendment or abolishment of laws, policies, program or other mechanisms for compliance with the articles contained in this Convention and whether this convention harmonizing with Islamic law which is applicable in Malaysia. In this study, the authors use methods such as interviews and documentation, library research and finally analyzed. The study found that there are some problem in the definition of "discrimination" under the CEDAW and Islamic Law in Malaysia, as well as the absence of a spesific law which provides clarification on the objectives and
\end{abstract}

\footnotetext{
Artikel ini merupakan Kertas Projek yang mendapat tempat kedua dalam pertandingan Kertas Projek Jabatan 
the establishment of the ratification of the CEDAW in Malaysia. These factors contributed to misunderstanding and criticism parties demanding equality between the sexes.

Keywords: sex discrimation against women, CEDAW, Malaysia, equality, religious aspects, Islamic law

\section{PENDAHULUAN}

Antara isu yang menjadi bualan hangat dan berkait dengan diskriminasi terhadap wanita adalah kes Beatrice a/p At Fernandez v Sistem Penerbangan Malaysia and Anor serta kes Noorfadila Ahmad Saikin v. Chayed Basirun yang memaparkan berkenaan kehamilan dan kesan yang membawa maksud diskriminasi dalam kerjaya wanita, perlantikan hakim wanita di Mahkamah Syariah serta laporan di dada akhbar yang menyatakan bahawa "diskriminasi gender, peluang wanita lebih sempit" telah membuka mata pihak-pihak dan di situlah dilihat seharusnya pendekatan CEDAW digunapakai rentetan kerajaan telah mula meratifikasikannya seawal tahun 1995. CEDAW telah mula berkuatkuasa pada tahun 1981 sebagai perjanjian hak asasi manusia antarabangsa pertama dan instrumen undang-undang utama, yang mana sebahagian besar peruntukannya adalah bagi memenuhi keperluan wanita. CEDAW meletakkan tuntutan terhadap wanita untuk hak-hak dan persamaan, dan menentukan rangka kerja undang-undang positif yang boleh digunakan untuk menentukan jaminan perlembagaan hak asasi wanita, untuk mentafsir undang-undang, untuk memulakan langkah proaktif sebagai suatu cara untuk menghapuskan diskriminasi.

Keunikan CEDAW terletak pada mandatnya untuk mencapai kesaksamaan substantif bagi wanita yang tidak hanya memerlukan kesaksamaan undangundang formal, tetapi juga hasil persamaan dalam nilai sebenar dengan mengiktiraf diskriminasi yang terhasil secara kontrak sosial, undang-undang, dasar dan amalan yang secara tidak langsung mempunyai kesan diskriminasi terhadap wanita. Konvensyen telah menetapkan kadar yang dinamik dan pendekatan proaktif untuk kemajuan wanita. Oleh itu, tiada istilah untuk menyatakan bahawa tidak ada diskriminasi terhadap wanita jika undangundang atau dasar yang secara terang-terangan menunjukkan telah berlaku diskriminasi terhadap wanita menurut konvensyen ini (Anuradha Rao and The International Women's Rights Action Watch, 2008: 13). 


\section{PRINSIP KONVENSYEN PENGHAPUSAN SEGALA BENTUK DISKRIMINASI TERHADAP WANITA}

Pada peringkat CEDAW, terdapat prinsip-prinsip yang harus dipatuhi untuk mewujudkan kebebasan yang ingin dicapai. Maksud hak kebebasan yang ingin ditegakkan adalah berdasarkan kepada tiga prinsip utama yang terdiri daripada prinsip kesetaraan substantif, prinsip tidak mendiskriminasi dan prinsip kewajipan negara yang meratifikasikannya. ${ }^{2}$

Prinsip yang pertama adalah prinsip untuk menyamakan hak kesaksamaan. ${ }^{3}$ Prinsip ini memperuntukkan untuk diadakan peluang yang sama untuk lelaki dan wanita. Bagi memperbetulkan diskriminasi yang telah berlaku terhadap wanita sebelum ini, konvensyen ini menyedari bahawa kaum wanita tidak berkongsi status "equality" dengan lelaki. Wanita telah dilayan dengan cara yang berbeza daripada lelaki pada suatu matlamat dan faedah yang sama. Dalam kebanyakan negara, wanita adalah dihalang untuk bekerja bagi pekerjaan yang memerlukan mereka untuk bekerja waktu malam. Alasan yang dinyatakan adalah wanita yang bekerja pada watu malam akan terdedah kepada keganasan.

Di sebalik rasional pendapat ini, kesan daripada halangan ini akan menyebabkan hak wanita untuk mempunyai peluang dalam pasaran ekonomi akan terjejas dan seterusnya mengetepikan wanita dengan hanya terlibat dalam tugasan domestik. Bagi menyelesaikan isu keselamatan wanita yang perlu bekerja pada waktu malam, maka pihak yang berwajib perlu menyediakan suasana bekerja yang selamat untuk kedua-dua gender baik lelaki mahupun wanita bagi mencapai matlamat yang diinginkan bagi prinsip pertama ini (Noor Aziah Mohd Awal, 2003: 3)

Bagi menjelaskan pemakaian prinsip ini, Islam menggambarkan gender sebagai dua entiti yang saling melengkapi antara satu sama lain. Tidak wujud persoalan bahawa Islam meletakkan pandangan yang negatif terhadap sebahagian ketidaksamataraan antara lelaki dan wanita. Ini adalah kesan daripada perbezaan semulajadi dan fizikal antara dua jantina berbeza yang

2 UN Women East and Southeast Asia Region. "The Principle of CEDAW," UN Women East and Southeast Asia Region United Nations Entity for Gender Equality and the Empowerment of Women, http://asiapacific.unwomen.org/en/focus-areas/ cedaw-human-rights, dicapai pada 14 Mac 2016.

3 UN Women East and Southeast Asia Region. "The Principle of CEDAW," UN Women East and Southeast Asia Region United Nations Entity for Gender Equality and the Empowerment of Women, http://asiapacific.unwomen.org/en/focus-areas/ cedaw-human-rights, dicapai pada 14 Mac 2016. 
menyebabkan berlaku secara tidak langsung perbezaan dari sudut luaran seseorang individu yang berlainan jantina dalam menjalani kehidupan seharian (Abdulssalam, Ahmad Shehu, 2006: 43)

Disebabkan terdapat perbezaan di antara lelaki dan perempuan dalam hukum Islam, telah muncul anggapan bahawa Islam tidak menjamin kesamarataan gender dan telah meletakkan kedudukan lelaki lebih tinggi berbanding wanita. Selain itu, adakah sebenarnya ketidakadilan tersebut bukan sebahagian daripada ajaran Islam sebaliknya tradisi masyarakat setempat atau ianya merupakan amalan yang menyimpang dari syariat Islam dan budaya tempatan yang baik (Mohd Anuar Ramli, 2012: 137-162).

Prinsip seterusnya menekankan bahawa tidak berlaku sebarang diskriminasi antara lelaki dan wanita (Anuradha Rao and The International Women's Rights Action Watch, 2008: 17). Konvensyen ini telah menetapkan maksud diskriminasi sebagai membawa kepada maksud sebarang perbezaan, pengecualian atau sekatan yang dibuat berdasarkan jantina yang mempunyai kesan menghalang atau menafikan pengiktirafan, penggunaan atau perlaksanaan oleh wanita, hak-hak dan kebebasan asasi manusia dalam bidang politik, ekonomi, sosial, budaya, kehidupan awam atau sebarang bidang lain (Suruhanjaya Hak Asasi Manusia, 2009: 3).

Melalui takrifan ini, diskriminasi terhadap wanita dalam semua aspek perlu dihapuskan bagi memastikan hak dan kebebasan wanita. Diskriminasi boleh terjadi sama ada secara langsung atau tidak langsung. Diskriminasi secara langsung memberi maksud diskriminasi yang dilakukan secara jelas. Contoh yang diberikan adalah melalui perbezaan peranan yang dimainkan antara dua gender seperti lelaki berperanan sebagai ketua keluarga manakala wanita lebih cenderung kepada melakukan kerja-kerja domestik. Seterusnya, diskriminasi tidak langsung pula adalah sesuatu yang tidak mempunyai matlamat untuk mendiskriminasi. Keadaan ini dapat dilihat melalui undang-undang dan budaya yang telah sebati dalam kalangan masyarakat kesan pembudayaan budaya patriarki yang diwarisi (Mohd Anuar Ramli, 2010: 49-70).

Contoh undang-undang yang mendiskriminasikan maksud konvensyen ini adalah umur anak perempuan boleh berkahwin lebih awal dari anak lelaki dalam Undang-Undang Keluarga Islam (Wilayah Persekutuan) $1984 .{ }^{4}$ Secara De Jure (undang-undang), anak-anak perempuan berkahwin awal adalah perkara yang biasa dan tidak berlaku sebarang diskriminasi. Manakala secara De Facto (fakta), anak perempuan tersebut akan tidak dapat menikmati

$4 \quad$ Akta Undang-Undang Keluarga Islam (Wilayah-wilayah Persekutuan), Seksyen 8 Stat. (1984). 
kebebasan dan terpaksa mengikut kehendak ibu bapa yang mempunyai akses secara menyeluruh untuk mengahwinkan anak perempuan pada usia muda dan terpaksa memikul, serta dibebani dengan tugasan domestik. Justeru itu, peranan wanita harus ditingkatkan sebagai penyelesai masalah dan pembuat keputusan dalam setiap lapangan untuk merubah stereotaip tingkat kuasa hanya pada kaum lelaki. ${ }^{5}$

Islam tidak mendiskriminasi manusia melalui gender dan perbezaan fungsi yang terjadi antara gender tidak bermakna memberi peninggian kepada satu jantina serta pengasingan kepada satu jantina yang lain.

Begitu juga hak wanita untuk menjadi pemimpin dalam sesuatu organisasi. Terdapat hadis yang menyatakan kegagalan sekiranya wanita memegang jawatan sebagai pemimpin tetapi hadis ini telah difahami secara luar dari konteks. Hadis ini sebenarnya adalah untuk mengkritik tindakan menaikkan anak perempuan Kerajaan Parsi ke atas takhta selepas ayahnya diturunkan takhta. Nabi menyebut di dalam hadis: ${ }^{6}$

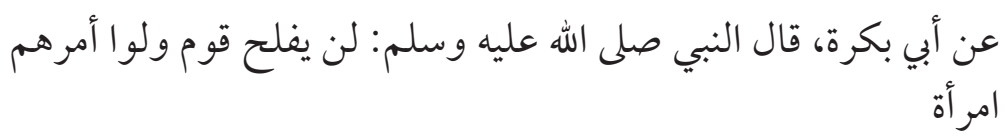

Dari Abu Bakrah radhiyallahu 'anhu, telah berkata Nabi Shallallahu 'alaihi wa sallam: "Tidak akan beruntung suatu kaum (bangsa) manakala menyerahkan urusan (kepimpinan) nya kepada seorang wanita."

Hadis ini mengkhususkan kepada anak perempuan pemerintah Parsi dan ini juga tidak berhubung dengan hadis yang menyatakan wanita kurang atau tidak sempurna dalam agama dengan mengambil kira keperluan saksi wanita 2: 1 dengan lelaki dalam sesetengah prosiding kehakiman dan transaksi perniagaan serta peredaran menstrual semulajadi wanita yang menyebabkan mereka diberi pengecualian dalam ibadah tertentu (al-Bukhari, 2009: 293).

Hujah-hujah ini tidak menunjukkan bahawa golongan wanita telah didiskriminasikan kerana terdapat konteks ayat memberi pengkhususan kepada kaum tertentu dan bukan menunjukkan kesemua wanita. Seterusnya

5 UN Women East and Southeast Asia Region. "The Principle of CEDAW," UN Women East and Southeast Asia Region United Nations Entity for Gender Equality and the Empowerment of Women, http://asiapacific.unwomen.org/en/focus-areas/ cedaw-human-rights, dicapai pada 14 Mac 2016.

6 Șaḥị al-Bukhārī (n.d.), Sharh Fatḥ al-Bārī. Qāhirah: Dār al-Salām, no. hadis 4425, Kitāb al-Maghāzi "Bab: Kitāb al-Nabiyyu 'alayh wa sallam illa Qusra wa Qaysir". 
perbezaan melakukan sesuatu bukannya terjadi atas alasan mengenepikan hak wanita di dalam konteks sosial, tetapi ia terjadi berdasarkan urf yang diambil kira pada waktu berkenaan dan juga sifat semulajadi wanita itu sendiri.

Bagi menentukan isu yang dikatakan sebagai mendiskriminasi gender di dalam prinsip Islam, perkara yang perlu diteliti adalah asal dari pengeluaran sesuatu hukum sama ada berdasar Syariah atau fiqh (Badlishah, Nik Noraini Nik, 2003: 32). Pemerhatian secara teliti perlu dibuat oleh sarjana Islam

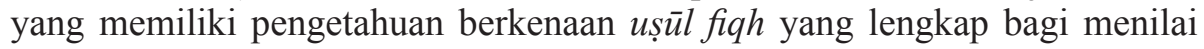
perbezaan tersebut bagi memastikan perbezaan antara kedua-duanya. Secara jelasnya, hukum Islam adalah bersumberkan kepada syariat Islam yang tiada ruang untuk berlakunya perubahan hukum.

Walaupun terma "diskriminasi" ditakrifkan di dalam Konvensyen 1980 ini, tetapi konvensyen ini tidak pula mendefinisikan pernyataan kesamarataan antara lelaki dan wanita (Ibid: 29). Disebabkan oleh ketiadaan maksud yang khusus berkenaan kesamarataan antara lelaki dan wanita, lalu menyebabkan berlakunya banyak persoalan berkenaan penanda aras untuk menyatakan bahawa golongan wanita telah didiskriminasikan.

Kesamarataan gender adalah merupakan isu utama dalam kewujudan Konvensyen CEDAW. Konvensyen CEDAW menjadikan kesamarataan gender sebagai asas untuk menghapuskan segala bentuk diskriminasi yang berlaku (Zuliza Mohd Kusrin \& Muhammad Hazuman Zulkifli, n.d.: 420).

Manakala prinsip terakhir adalah prinsip kepatuhan negara yang meratifikasikan Konvensyen Penghapusan Segala Bentuk Diskriminasi Terhadap Wanita (CEDAW). ${ }^{7}$ Malaysia sebagai sebuah negara yang telah meratifikasikan CEDAW adalah berkewajipan untuk memberi laporan setiap empat tahun sekali kepada jawatankuasa CEDAW. Laporan ini perlu merangkumi laporan mengenai pematuhan kepada hak asasi wanita dari aspek penghormatan, perlindungan dan promosi hak asasi wanita berasaskan CEDAW. Bagi memenuhi aspek penghormatan, perlulah memenuhi empat isu utama iaitu tidak boleh melanggar hak asasi wanita, meningkatkan usaha untuk menaikkan kedudukan hak asasi wanita, tidak membuat dan mengubal peraturan dan undang-undang yang mendiskriminasi wanita (Ibid).

Negara yang meratifikasikan CEDAW wajib menghapus segala undangundang yang mendiskriminasi wanita di peringkat kebangsaan mahupun di

\footnotetext{
UN Women East and Southeast Asia Region. "The Principle of CEDAW," UN Women East and Southeast Asia Region United Nations Entity for Gender Equality and the Empowerment of Women, http://asiapacific.unwomen.org/en/focus-areas/ cedaw-human-rights, dicapai pada 14 Mac 2016.
} 
negeri-negeri. Manakala perlindungan hak asasi wanita wajib dilakukan oleh negara dengan cara memastikan adanya mekanisme untuk menerima aduan, dilaksanakan keadilan dan pembayaran ganti rugi apabila terdapat sesuatu kes berhubung diskriminasi. Di samping itu, CEDAW juga berperanan dalam memastikan dan mengawasi tindak tanduk pihak institusi swasta, koperasi dan individu agar tidak melanggar hak asasi wanita, melarang diskriminasi dan menjatuhkan hukuman terhadap tindakan yang mendiskriminasi wanita (Ibid).

Negara yang meratifikasikan CEDAW adalah berkewajipan untuk melaksanakan segala yang dihuraikan di dalam prinsip ini dan sekiranya manamana negara tidak melakukan kewajipan yang ditetapkan dan mengabaikannya, bermakna negara tersebut telah bertindak untuk melanggar hak asasi wanita.

\section{KESAN RATIFIKASI CEDAW DI MALAYSIA KESAN MENURUT UNDANG-UNDANG}

\section{Pindaan ke Atas Perlembagaan Persekutuan Melarang Diskriminasi Gender}

Di dalam Perkara 8 Perlembagaan Persekutuan, berhubung "kesamarataan" telah dipinda pada tahun 2001 dengan memasukkan unsur gender dalam peruntukan tersebut. Iaitu di dalam subseksyen (2) Perkara 8 telah menyatakan bahawa:

"Kecuali sebagaimana yang dibenarkan dengan nyata oleh Perlembagaan ini, tidak boleh ada diskriminasi terhadap warganegara semata-mata atas alasan agama, ras, keturunan, tempat lahir atau jantina dalam mana-mana undang-undang atau dalam pelantikan kepada apa-apa jawatan atau pekerjaan di bawah sesuatu pihak berkuasa awam atau dalam pentadbiran mana-mana undang-undang atau sektor swasta atau badanbadan bukan kerajaan yang berhubungan dengan penubuhan atau perjalanan apa-apa pertukangan, perniagaan, profession, kerjaya atau pekerjaan atau polisi..."

Menerusi pindaan ini, keluasan tafsiran ke atas Perlembagaan Persekutuan tidak terhad hanya mengikat pihak berkuasa awam bahkan juga akan mengikat setiap pihak di dalam negara. Pindaan ini akan melindungi setiap daripada rakyat Malaysia daripada dieksploitasi oleh diskriminasi terhadap gender dan lain-lain bentuk diskriminasi berdasarkan agama, ras, keturunan dan tempat 
lahir. ${ }^{8}$ Keluasan dan kesempitan tafsiran diskriminasi gender ini akan dilihat menerusi pemutusan kes yang akan dihuraikan selepas ini.

Artikel 26 Konvensyen Vienna di dalam Undang-Undang Triti 1969 menyatakan bahawa setiap triti yang dikuatkuasakan adalah mengikat pihak-pihak yang memasukinya, serta mesti dilaksanakan sebaik mungkin. Konvensyen Penghapusan Segala Bentuk Diskriminasi Terhadap Wanita (CEDAW) adalah antara triti yang telah dikuatkuasakan dan komitmen Malaysia terhadap Konvensyen CEDAW telah diperkuatkan apabila Artikel 8(2) Perlembagaan Persekutuan dipinda untuk menunjukkan kesatuan dengan artikel yang terdapat di dalam Konvensyen CEDAW.

\section{Pindaan ke Atas Akta Penjagaan Kanak-Kanak 1961}

Antara perundangan bertulis yang mendapat kritikan yang hebat atas alasan diskriminasi terhadap wanita ialah Akta Penjagaan Budak 1961. Akta 1961 ini telah memberikan hak yang lebih tinggi kepada bapa dalam soal untuk menjaga kanak-kanak. Bapa adalah penjaga utama kepada kanak-kanak sebelum ibu, pengisytiharan ibu hanya berlaku apabila bapa meninggal dunia ${ }^{9}$ menurut Seksyen 6 Akta 1961. Situasi ini memberikan gambaran bahawa wujud suatu penanda aras bahawa bapa adalah penjaga di sisi undang-undang ke atas seorang kanak-kanak dan hak ibu ke atas kanak-kanak adalah lebih rendah daripada bapa.

Peruntukan Seksyen 6 Akta 1961 ini bukan sahaja menyatakan bahawa peranan ibu hanya akan mengambil tempat setelah bapa meninggal dunia, tetapi haknya juga dihadkan apabila mahkamah masih boleh melantik orang lain untuk bertindak sebagai penjaga kanak-kanak itu bersama dengan si ibu atau ianya memberi maksud bahawa apabila seseorang ibu itu adalah "surviving parent". Hak yang didapatinya sebagai penjaga utama adalah tidak mutlak dan pengenaan syarat yang lebih ketat berbanding apabila bapa memiliki hak tersebut, yang mana tiada syarat sampingan yang diperuntukkan terhadapnya. ${ }^{10}$

Walau bagaimanapun, peruntukan ini telah pun dipinda untuk memberi ibu dan bapa hak yang sama dalam hak penjagaan ke atas anak mereka. Langkah

$8 \quad$ Siti Zaihan Zulkarnain (Penolong Setiausaha Bahagian Polisi, Undang-Undang dan Aduan Suruhanjaya Hak Asasi Manusia), dalam temu bual beliau bersama penulis, pada 13 Mei 2015.

9 Seksyen 6, Akta Penjagaan Budak 1961.

10 Siti Zaihan Zulkarnain (Penolong Setiausaha Bahagian Polisi, Undang-Undang dan Aduan Suruhanjaya Hak Asasi Manusia), dalam temu bual beliau bersama penulis, pada 13 Mei 2015. 
ini merupakan salah satu usaha bagi mematuhi Konvensyen CEDAW di Malaysia.

\section{Prinsip Kewarganegaraan dalam Perlembagaan Persekutuan}

Perlembagaan Persekutuan juga telah menetapkan bahawa pemberian status kewarganegaraan Malaysia kepada kanak-kanak yang dilahirkan di luar negara masih lagi menunjukkan elemen diskriminasi terhadap wanita. Hanya mereka yang memiliki bapa kerakyatan Malaysia boleh mendapat status warganegara secara automatik. Wanita Malaysia yang melahirkan anak hasil perkahwinannya dengan warga asing perlu membuat permohonan bagi mendapatkan hak kerakyatan anak mereka. ${ }^{11}$

Malaysia telah menyatakan reservasi terhadap Artikel 9(2) berasaskan percanggahannya dengan peruntukan Perlembagaan Malaysia. Malaysia turut mengisytiharkan bahawa reservasi tersebut hanya akan dinilai semula setelah akta dan undang-undang yang berkaitan dipinda. Walau bagaimanapun, sehingga ke saat ini kerajaan masih belum menilai semula undang-undang yang berkaitan isu kewarganegaraan. ${ }^{12}$

SUHAKAM menyeru agar kerajaan Malaysia menilai semula perkara ini dengan merujuk kembali kepada Perkara 8(2) Perlembagaan Persekutuan yang jelas memperuntukkan bahawa tidak boleh wujud diskriminasi terhadap warganegara semata-mata atas alasan agama, ras, keturunan, tempat lahir atau jantina dalam mana-mana undang-undang. ${ }^{13}$ Oleh itu, menurut SUHAKAM, Perkara 14 dan 15 Perlembagaan Persekutuan hendaklah dibaca bersamasama dengan Perkara 8(2) untuk meluaskan penggunaan prinsip kesaksamaan jantina di dalam isu yang berkaitan dengan kewarganegaraan (Ibid).

Dalam Mesyuarat Persidangan Meja Bulat, wakil daripada Kementerian Dalam Negeri (KDN) telah menyatakan antara faktor-faktor yang diambil kira bagi menentukan status kewarganegaraan seseorang anak, iaitu status kewarganegaraan ibu dan ayah, status perkahwinan ibu dan ayah, tempat kelahiran anak tersebut sama ada di dalam atau luar Persekutuan, serta faktor umur anak tersebut (Suruhanjaya Hak Asasi Manusia Malaysia, 2015: 13).

11 Siti Zaihan Zulkarnain (Penolong Setiausaha Bahagian Polisi, Undang-Undang dan Aduan Suruhanjaya Hak Asasi Manusia), dalam temu bual beliau bersama penulis, pada 13 Mei 2015.

12 Siti Zaihan Zulkarnain (Penolong Setiausaha Bahagian Polisi, Undang-Undang dan Aduan Suruhanjaya Hak Asasi Manusia), dalam temu bual beliau bersama penulis, pada 13 Mei 2015.

13 Perkara 8(2), Perlembagaan Persekutuan Malaysia 
Melihatkepada Perkara 14(1)(b)dan Bahagian II Jadual Kedua Perlembagaan Persekutuan berkaitan kewarganegaraan berdasarkan penguatkuasaan undang-undang bagi orang yang pada atau selepas hari Malaysia, wakil dari Kementerian Dalam Negeri mengakui bahawa peruntukan tersebut tidak terpakai kepada anak hasil perkahwinan antara wanita warganegara dan lelaki bukan warganegara yang lahir di luar Persekutuan. Akan tetapi, ibu kepada anak tersebut boleh membuat permohonan untuk anak tersebut menjadi warganegara di bawah perkara 15(2) Perlembagaan Persekutuan (Ibid: 13).

Antara alasan yang telah diberikan oleh pihak kerajaan untuk tidak memberikan taraf kewarganegaraan secara terus kepada anak hasil perkahwinan wanita warganegara dan lelaki bukan warganegara adalah kerana Malaysia tidak mengiktiraf dwi-kewarganegaraan seperti yang telah diperuntukkan dalam Perkara 24 Perlembagaan Persekutuan. Malaysia dan beberapa negara lain masih mengamalkan sistem patriarkal dalam isu kewarganegaraan, yang mana ia berpegang pada prinsip bahawa seseorang anak daripada hasil perkahwinan yang sah adalah mewarisi kewarganegaraan bapanya serta dasar kerajaan berkenaan penetapan pemberian taraf kewarganegaraan yang boleh diberikan dalam hal-hal tertentu melalui permohonan.

Kerajaan berpendapat bahawa ia perlu berhati-hati memandangkan Malaysia merupakan negara tumpuan bagi pendatang asing tanpa izin dan dasar-dasar mengenai kewarganegaraan adalah merupakan salah satu cara untuk mengawal kemasukan pendatang tanpa izin (Ibid: 14).

Justeru itu, berdasarkan pengamatan penulis, isu berhubung Artikel 9(2) adalah bersifat teknikal dan boleh ditarik reservasi setelah kerajaan menetapkan prosedur tertentu dan mengenakan syarat tertentu untuk wanita yang berkahwin dengan lelaki bukan warganegara.

\section{Wanita dan Pekerjaan}

Dalam Akta Pekerjaan 1955, terdapat beberapa syarat khas untuk mereka berasa selesa dan menjaga keselamatan mereka. Seksyen 34 Akta Kerja 1955 menyatakan larangan bekerja malam bagi wanita dari jam 10.00 malam hingga 5.00 pagi, kecuali dengan kelulusan Ketua Pengarah Sumber Manusia. ${ }^{14}$ Pada kebiasaannya, kelulusan akan diberikan dengan syarat majikan menyediakan pengangkutan percuma untuk mengambil dan menghantar pekerja. Seksyen 35 akta yang sama juga mensyaratkan pekerja-pekerja wanita tidak boleh diambil bekerja dalam mana-mana kerja bawah tanah. ${ }^{15}$ Peruntukan ini mungkin kelihatan sangat mulia dalam niatnya untuk melindungi wanita, akan

14 Seksyen 34, Akta Kerja 1955.

15 Seksyen 35, Akta Kerja 1955. 
tetapi secara faktanya, ianya adalah satu bentuk diskriminasi bagi wanita yang dilihat sebagai "golongan yang perlu dilindungi" kerana mereka adalah lemah (Noor Aziah Mohd Awal, 2003: 89).

Terdapat peruntukan di dalam Akta Pekerjaan iaitu cuti bersalin selama 60 hari $^{16}$ iaitu di bawah Seksyen 37 akta tersebut. Tempoh ini berdasarkan ketetapan yang telah ditetapkan oleh Organisasi Buruh Antarabangsa (ILO) iaitu selama 90 hari. Antara perkara lain yang tidak mengikut standard yang telah ditetapkan oleh ILO adalah termasuk elaun asuhan dan penjagaan serta kemudahan untuk ibu yang menyusukan anak. Kerajaan telah menyediakan pelepasan cukai bagi menguatkan atau mengiatkan penguatkuasaan peruntukan untuk menyediakan pusat penjagaan kanak-kanak di tempat kerja. Akan tetapi peruntukan tersebut tidak memberikan kesan yang mandatori. Akta Pekerjaan juga tidak menyatakan bahawa majikan mesti memberi gaji yang sama antara lelaki dan wanita untuk suatu pekerjaan yang sama walaupun Malaysia telah meratifikasikan Konvensyen ILO No.100 untuk persamaan gaji antara lelaki dan wanita pada tahun 1997 (Ibid: 90).

Di samping itu, bagi isu pembantu rumah warga asing yang kebanyakannya adalah wanita, mereka tidak didefinisikan sebagai pekerja. Oleh itu, mereka tidak dapat menerima faedah daripada Akta Kumpulan Wang Simpanan Pekerja 1991 dan Akta Keselamatan Sosial Pekerja 1969. Usaha telah dibuat melalui Rang Undang-Undang dengan memasukkan selepas takrif "pekerja" yang berikut iaitu "pembantu rumah warga asing" yang bermaksud pembantu rumah yang bukan warganegara atau memiliki pemastautin tetap (Ibid: 90).

\section{PANDANGAN POSITIF TERHADAP PERLAKSANAAN CEDAW DI MALAYSIA DARI SUDUT UNDANG-UNDANG}

Jawatankuasa CEDAW telah memberi kredit terhadap Malaysia bagi pencapaian membangunkan wanita dalam bidang pendidikan. Pujian diberikan kepada Malaysia dalam rangka penubuhan Jawatankuasa dalam Kesaksamaan Gender dan Gender Focal Point dalam pelbagai kementerian, dan di dalam pindaan terhadap (i) Akta Pencen iaitu untuk memastikan bahawa balu penjawat awam tidak kehilangan pencen mereka di atas perkahwinan semula (ii) Land (Group Settlement Areas) Act bagi membenarkan isteri atau bekas isteri peneroka untuk menjadi pemilik bersama dan (iii) Kanun Keseksaan dalam menaikkan penalti bagi kesalahan merogol dan sumbang mahram (Committee on the Elimination of Discrimination Against Women, 2006: 305-306).

16 Seksyen 37, Akta Kerja 1955. 
Jawatankuasa juga turut memuji tindakan Malaysia bagi usaha berterusan untuk mewujudkan pembaharuan undang-undang berkenaan keganasan terhadap wanita. Ini termasuklah inisiatif terbaru untuk meminda (i) Akta Keganasan Rumah Tangga dan meluaskan definisi keganasan rumah tangga dan meningkatkan langkah-langkah untuk melindungi mangsa dan juga perubahan menerusi (ii) Akta Kerja 1955, Akta Perhubungan Perusahaan 1967 dan Akta Keselamatan dan Kesihatan Pekerjaan 1994 dengan menambah peruntukan yang melarang gangguan seksual (Ibid: 306).

\section{KESAN MENURUT HUKUM SYARAK}

\section{Undang-Undang Keluarga Islam di Malaysia dari Perspektif Perkara 16 Konvensyen CEDAW}

Dalam perbincangan meja bulat mengenai reservasi terhadap konvensyen antarabangsa iaitu: Konvensyen Penghapusan Segala Bentuk Diskriminasi Terhadap Wanita (CEDAW), Konvensyen Mengenai Hak Kanak-Kanak (CRC) dan Konvensyen Mengenai Hak Orang Kurang Upaya (CRPD), Najibah Mohd Zain memberikan penjelasan berkenaan artikel tersebut bahawa Malaysia telah meletakkan reservasi terhadap Artikel 16(1)(a), (c), (f), dan (g) (Suruhanjaya Hak Asasi Manusia Malaysia, 2015: 9).

Artikel tersebut adalah berkait dengan hak-hak wanita dalam perkara yang berkaitan hubungan perkahwinan dan kekeluargaan. Alasan yang dikemukakan oleh kerajaan untuk meletakkan reservasi ke atas artikel tersebut adalah kerana bertentangan dengan hukum Syarak, Undang-undang Syariah dan juga Perlembagaan Persekutuan.

Menurut penjelasan Najibah Mohd Zain, tujuan utama Artikel 16 Konvensyen CEDAW adalah bagi mewujudkan suasana hormat-menghormati dalam hubungan kekeluargaan antara suami, isteri dan anak. Hal ini berikutan kerana masih terdapat negara-negara yang membenarkan penganiayaan ke atas wanita termasuklah hak wanita ke atas penjagaan anak, pengabaian tanggungjawab nafkah oleh suami dan juga keganasan rumah tangga (Ibid: 11).

\section{Isu Artikel 16(1)(a)}

Bagi isu berkenaan Artikel 16(1)(a), beliau telah menghuraikan dua prinsip utama berkaitan perlaksanaan Artikel 16(1)(a). Yang pertama adalah mengenai 
hak yang sama untuk berkahwin dan yang kedua adalah hak yang sama rata dalam memilih pasangan untuk berkahwin (Ibid: 9-10).

Hak yang sama rata untuk berkahwin, prinsip ini bertujuan untuk menghalang perkahwinan dibuat secara paksaan terhadap wanita dan kanakkanak perempuan khususnya. Berdasarkan peruntukan di bawah Seksyen 13 Akta Undang-Undang Keluarga Islam (Wilayah-wilayah Persekutuan) 1984 [Akta 303] telah menyatakan bahawa sesuatu perkahwinan adalah tidak diakui sah dan tidak boleh didaftarkan melainkan kedua-dua pihak kepada perkahwinan itu telah bersetuju terhadapnya. ${ }^{17}$

Manakala prinsip kedua bagi perlaksanaan Artikel 16(1)(a) adalah hak yang sama dalam memilih pasangan untuk berkahwin. Mengikut konsep Islam yang sebenar, lelaki dan wanita mempunyai hak yang sama rata untuk berkahwin. Akan tetapi, terdapat beberapa perkara yang disyaratkan dalam Islam sebelum berlakunya perkahwinan antara lelaki dan perempuan. Antara syarat yang perlu dipatuhi adalah seseorang wanita perlu mendapatkan kebenaran daripada wali sebelum berkahwin dengan mana-mana lelaki. ${ }^{18}$ Wali yang dimaksudkan di sini adalah seorang bapa atau datuk serta susunan wali yang telah ditetapkan syarak sekiranya tiada kedua-duanya.

Imam Mālik̄̄, Shāfi ‘̄i dan Hanbalī berpendapat bahawa seseorang wali tidak berhak untuk memaksa seorang wanita berkahwin meskipun dia berautoriti untuk melaksanakan akad tersebut. Dia juga tidak berhak untuk melakukan akad tersebut tanpa adanya izin dari wanita yang dinikahkannya beserta kerelaannya yang jelas (Sayyid Sabiq, 2008: 241). Walaupun wali merupakan rukun nikah dan wajib dipenuhi, akan tetapi terdapat suatu prosedur tuntutan wali enggan sekiranya wali nasab tersebut membantah pernikahan seseorang wanita (Syaikh Abdul Rahman al-Juzairi, 2011: 34). Justeru itu, pandangan ini tidak menjejaskan konsep CEDAW dan ternyata wanita juga mempunyai hak yang sama untuk berkahwin.

Intepretasi yang luas menimbulkan kegelisahan dalam kalangan masyarakat bahawa Artikel 16(1)(a) ini akan menggalakkan perkahwinan sesama jantina, perkahwinan terlarang seperti perkahwinan ibu mentua dan menantu serta lainlain hubungan yang dilarang oleh Islam. Situasi ini dapat dielakkan melalui penjelasan bahawa di Malaysia, perkahwinan yang sah adalah terdiri daripada lelaki dan wanita. Menurut Seksyen 59 Akta Undang-Undang Pembaharuan

17 Seksyen 13, Akta Undang-Undang Keluarga Islam (Wilayah-wilayah Persekutuan) 1984.

18 Seksyen 7, Akta Undang-Undang Keluarga Islam (Wilayah-wilayah Persekutuan), 1984. 
Perkahwinan dan Penceraian 1976 [Akta 164] telah memperuntukkan bahawa sesuatu perkahwinan terbatal jika pasangan tersebut adalah secara biologi didapati bukan lelaki atau bukan wanita. ${ }^{19}$

\section{Isu Berkaitan Artikel 16(1)(c)}

Di dalam artikel ini, prinsip-prinsip yang dibawa adalah berkaitan hak dan tanggungjawab yang sama rata antara suami dan isteri semasa perkahwinan serta hak dan tanggungjawab yang sama antara suami dan isteri selepas perceraian (Ibid: 10).

Menurut Islam, suami dan isteri mempunyai hak yang sama dalam mengemudi institusi kekeluargaan. Perkara ini adalah dapat dijelaskan menerusi peruntukan Seksyen 60 [Akta 303] yang memperuntukkan berkenaan tanggungjawab pihak suami untuk memenuhi isteri dan anak seperti menyediakan nafkah (kewangan) manakala tuntutan dari pihak isteri pula adalah untuk memenuhi keperluan suami dan juga anak-anak dalam bentuk ketaatan dan memelihara kehormatan diri, rumahtangga dan harta sewaktu ketiadaan suami.

Berdasarkan Seksyen 72 akta yang sama juga menyatakan bahawa kewajipan nafkah anak turut diletakkan ke atas suami. Perkara ini juga adalah bersamaan dengan konsep yang disepakati oleh ulama mazhab, yang mana mereka telah mengklasifikasikan hak isteri ke atas suami adalah mencakupi hak kebendaan iaitu mahar dan nafkah serta hak rohaniah yang mencakupi kewajipan untuk suami bersikap adil jika berpoligami dan tidak boleh membuat isteri sengsara.

Dari segi hak dan tanggungjawab yang sama antara suami dan isteri selepas penceraian pula adalah berkenaan mereka kedua-duanya mempunyai hak untuk membubarkan perkahwinan tetapi dengan cara yang berbeza. Sebagai penjelasan, suami mempunyai hak untuk membubarkan perkahwinan dengan cara talak dan fasakh manakala dari pihak isteri pula boleh membubarkan dengan cara ta 'liq, khulu' dan fasakh.

Selain itu, isu lain yang timbul adalah tuntutan ke atas pihak suami yang acap kali mengabaikan tanggungjawab dalam membayar nafkah seperti nafkah tempat tinggal, pendidikan anak-anak, kewangan dan lain-lain selepas berlaku penceraian. Di samping itu, Seksyen 59 (Akta 303) berkenaan peuntukan kesan nusyuz ke atas isteri oleh suami turut dilihat sebagai bercanggah dengan prinsip di dalam Artikel 16(1)(c). Seksyen ini menyebut bahawa seseorang isteri tidak berhak untuk mendapat nafkah apabila dia disabitkan nusyuz.

19 Seksyen 59, Akta Undang-Undang Pembaharuan Perkahwinan dan Penceraian 1976. 
Peruntukan ini telah dikatakan memberikan kuasa kepada suami dan dikatakan boleh mendorong kepada keganasan rumah tangga.

Akan tetapi penjelasan yang jelas juga perlu diberikan oleh pihak-pihak yang berwajib seperti isu perwalian di atas, ini kerana pensabitan nusyuz tidak sewenang-wenangnya akan di sabitkan ke atas seseorang isteri melainkan dengan pembuktian yang kukuh dan hikmah atas hukuman ini adalah untuk menjamin institusi perkahwinan yang damai dan toleransi.

\section{Perkahwinan Kanak-Kanak}

Isu yang berlaku adalah berdasarkan perbezaan umur untuk kedua-duanya memasuki atau memulakan perkahwinan. Seksyen 8 [Akta 303] telah memperuntukkan bahawa had umur minima untuk seorang lelaki memasuki alam perkahwinan adalah 18 tahun manakala kanak-kanak perempuan pada umur 16 tahun. ${ }^{20}$ Akan tetapi, bagi kanak-kanak perempuan yang berusia bawah had umur mimima, kebenaran bertulis akan diberikan untuk berkahwin daripada Mahkamah Syariah sebelum perkahwinan dijalankan.

Ulama Mazhab al-Shāfi'ī menganggap sunat agar ayah dan datuk tidak mengahwinkan gadis yang masih dalam usia kanak-kanak sehingga dia mencecah umur dewasa serta perlunya kepada permintaan kebenaran terlebih dahulu daripada anak tersebut. Manakala bagi pendapat jumhur ulama, mereka berpendapat bahawa wali selain ayah dan datuk tidak boleh mengahwinkan perempuan yang masih dalam usia kanak-kanak dan sekiranya ianya terjadi, maka perkahwinan tersebut dihukumkan sebagai tidak sah. Maka di sini jelas menunjukkan bahawa pengeluaran hukum oleh ulama-ulama mazhab adalah dengan mengambil kira elemen menghormati dan memuliakan wanita (Sayyid Sabiq, 2008: 182).

Berdasarkan temu bual yang dijalankan bersama pegawai dari SUHAKAM, beliau telah menyatakan pendapatnya bahawa umur kanak-kanak atau dewasa perlu diselaraskan antara undang-undang Islam dan Sivil dan persamaan umur untuk memasuki perkahwinan antara lelaki dan perempuan. Hal ini kerana kapasiti biologi kanak-kanak pada usia tersebut adalah masih tidak terbentuk dengan sepenuhnya dan akan menganggu mental kanak-kanak yang sedang dalam tempoh perubahan yang ketara dan kritikal pada waktu tersebut. ${ }^{21}$

20 Seksyen 8, Akta Undang-Undang Keluarga Islam (Wilayah-wilayah Persekutuan) 2003.

21 Siti Zaihan Zulkarnain (Penolong Setiausaha Bahagian Polisi, Undang-Undang dan Aduan Suruhanjaya Hak Asasi Manusia), dalam temu bual beliau bersama penulis, pada 13 Mei 2015. 


\section{Isu Keadilan dalam Pengagihan Harta Pusaka}

Malaysia telah menarik balik reservasi yang diletakkan atas Artikel 16(1)(h). Menurut Najibah Mohd Zain, terdapat beberapa isu yang timbul berkaitan perlaksanaan Artikel ini, iaitu Artikel ini dikatakan bertentangan dengan undang-undang pusaka iaitu hukum faraid apabila hak wanita adalah lebih sedikit berbanding hak lelaki (Suruhanjaya Hak Asasi Manusia Malaysia, 2015: 1-35).

Undang-undang pusaka Islam telah menerima kritikan oleh golongan yang menuntut persamaan untuk antara lelaki dan wanita. Golongan ini mempersoalkan kenapa waris lelaki dalam pusaka Islam mendapat bahagian yang lebih berbanding dengan waris perempuan dan apakah rasionalnya alQuran menetapkan bahagian waris lelaki menyamai dua bahagian waris perempuan dalam pembahagian semua harta pusaka Islam. Pada pandangan mereka, ini adalah salah satu aspek ketidakadilan yang berlaku dalam pengagihan harta pusaka menurut hukum Syarak kerana bahagian atau syer waris perempuan tidak menyamai bahagian waris lelaki dan ia merupakan satu perbuatan diskriminasi terhadap kaum wanita dalam pemilikan harta melalui pembahagian harta pusaka (Mohd Ridzuan Awang, 2008: 115).

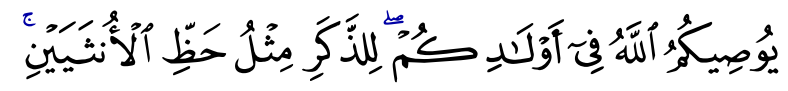

"Allah perintahkan kamu mengenai (pembahagian harta pusaka
untuk) anak-anak kamu, iaitu bahagian seorang anak lelaki
menyamai bahagian dua orang anak perempuan..."

(Surah al-Nisā', 4: 11)

Ayat di atas menyatakan bahawa bahagian seorang anak lelaki, menyamai bahagian dua orang anak perempuan. Hikmah daripada penetapan ini menurut Islam adalah disebabkan lelaki mempunyai tanggungjawab yang lebih dari sudut kewajipan menyediakan nafkah dan penetapan yang diberikan ini bukanlah semata-mata untuk melebihkan kaum lelaki. Kecaman dari feminisme menyatakan bahawa lelaki tidak secara konkrit menanggung nafkah dan dewasa ini menunjukkan peranan wanita lebih berdikari dan tidak dipertanggungkan dengan nafkah oleh suami. Justeru itu, penulis merasakan perlu suatu penggubalan undang-undang bagi memastikan pihak lelaki memenuhi tanggungjawab yang sepatutnya bagi melayakkan pihak lelaki mendapatkan bahagian yang lebih seperti yang ditetapkan bagi memastikan hikmah penetapan pembahagian lelaki lebih daripada wanita benar-benar dilaksanakan. 
Di dalam perbincangan Meja Bulat SUHAKAM, Pesuruhjaya SUHAKAM iaitu Mahmood Zuhdi Abdul Majid selaku moderator kepada perbincangan menerangkan berkenaan salah faham yang sering timbul dalam kalangan rakyat Malaysia khususnya berkenaan hukum pembahagian harta menurut Islam. Beliau menyuarakan pandangan bahawa hukum faraid bukanlah satusatunya cara pembahagian harta yang wajib dilaksanakan oleh orang Islam. Ia merupakan langkah terakhir sekiranya kaedah pembahagian harta lain tidak digunakan oleh pemilik harta semasa hayatnya seperti hibah, sedekah dan lain-lain lagi. Walaupun si mati tidak sempat mengambil langkah lain, hukum faraid boleh untuk tidak dilaksanakan sekiranya semua ahli waris bersetuju untuk melaksanakan pembahagian dengan kaedah yang lain (Suruhanjaya Hak Asasi Manusia Malaysia, 2015: 17).

\section{KESAN KE ATAS SISTEM KEHAKIMAN DI MALAYSIA}

\section{Keputusan Kes Beatrice A/P Fernandez v. Sistem Penerbangan Malaysia \& Anor}

Di dalam kes Beatrice a/p At Fernandez v. Sistem Penerbangan Malaysia and Anor. Tafsiran yang dibuat oleh mahkamah yang dikenali sebagai "vertical effect", di mana undang-undang perlembagaan terpakai apabila hak-hak individu telah dilanggar oleh Pihak Berkuasa Awam, jika pelanggaran itu dibuat oleh entiti swasta, remedi yang boleh dituntut adalah di bawah undangundang "private" kerana remedi dari undang-undang perlembagaan adalah tidak terpakai (Maizatul Azila Chee Din et al., 2011: 29-33).

Diskriminasi boleh berlaku sama ada di sektor awam atau swasta dan boleh diklasifikasikan sebagai diskriminasi secara langsung atau tidak langsung. Diskriminasi secara langsung merujuk kepada keadaan apabila seseorang diperlakukan secara teruk berbanding orang lain walaupun mereka dalam keadaan yang sama. Manakala diskriminasi secara tidak langsung merujuk kepada keadaan di mana semua orang kelihatan dilayan secara sama rata berdasarkan kaedah atau kehendak yang sama tetapi ia seolah-olah dipatuhi oleh kumpulan tertentu (Sara Charlesworth, 2008: 13).

Dalam kes ini, Beatrice (perayu) adalah pekerja kepada Syarikat Penerbangan Malaysia (responden) sebagai Pramugari Kelas B. Perjanjian kolektif bertarikh 3 Mei 1998 telah menyatakan terma-terma dan syaratsyarat perkhidmatan beliau. Artikel 2(3) Perjanjian Kolektif mengkehendaki semua pramugari (agensi yang sama) untuk meletak jawatan selepas hamil. 
Responden pertama berhak untuk membatalkan servis beliau walaupun beliau menolak untuk diberhentikan.

Perayu enggan untuk berhenti apabila dia disahkan hamil dan telah ditamatkan perkhidmatannya oleh Responden. Ini menyebabkan beliau bertindak untuk menfailkan tindakan undang-undang di Mahkamah Tinggi dengan mengemukakan peruntukan Perjanjian Kolektif adalah mendiskriminasi. Oleh itu, tindakan tersebut telah melanggar Artikel 8 Perlembagaan Persekutuan Malaysia dan menjadikan Perjanjian Kolektif tersebut tidak sah. Mahkamah Tinggi dan Mahkamah Rayuan menolak permohonannya. ${ }^{22}$ Perayu kemudian memohon kebenaran untuk merayu kepada Mahkamah Persekutuan. ${ }^{23}$

Kehamilan adalah sebahagian daripada identiti wanita yang mempunyai keupayaan reproduktif dan kerana ia adalah fungsi sosial jadi wanita tidak boleh untuk didiskriminasikan oleh sebab kehamilan, terutama dalam bidang pekerjaan. Dalam konteks Malaysia, walaupun ratifikasi yang dibuat kepada Konvensyen CEDAW dan pindaan kepada Perlembagaan Persekutuan pada tahun 2001 yang menambah perkataan "jantina" ke dalam Artikel 8(2) Perlembagaan Persekutuan untuk melarang diskriminasi. Akan tetapi tafsiran semasa mahkamah dalam menegakkan hak wanita untuk mencapai kesaksamaan dan melarang sebarang diskriminasi gender adalah sempit dan dilihat sebagai tidak mencukupi untuk memberikan kesaksamaan gender secara penuh. Hal ini menyebabkan kesusahan yang tidak wajar bagi pihak wanita untuk mendapatkan perlindungan penuh dari Perlembagaan Persekutuan.

\section{Keputusan Kes Noorfadila Ahmad Saikin v. Chayed Basirun ${ }^{24}$}

Di dalam kes ini, Plaintif telah memohon untuk mendapat pekerjaan sebagai Guru Sandaran Tidak Terlatih (GSTT). Setelah menerima memo penempatan berkenaan pemberitahuan tentang jawatannya, dia telah diminta untuk menghadiri taklimat berhubung terma-terma pekerjaan perkhidmatannya. Sewaktu taklimat ini, Plaintif telah disoal sama ada dia hamil. Apabila Plaintif mengakui dia hamil tiga bulan, memo penempatannya telah dibatalkan. Plaintif telah menuntut agar pekerjaannya sebagai GSTT dikembalikan semula, tetapi beliau tidak menerima sebarang jawapan bertulis.

\footnotetext{
22 Beatrice A/P Fernandez v. Sistem Penerbangan Malaysia \& Anor [2004] 4 MLJ 466.

23 Beatrice A/P Fernandez v. Sistem Penerbangan Malaysia \& Anor [2004] 3 MLJ 681.

24 Noorfadilla Ahmad Saikin v. Chayed Basirun [2012] 1 MLJ.
} 
Telah diputuskan bahawa mahkamah membenarkan permohonan tanpa perintah untuk kos. Hakim Bicara dalam penghakimannya telah memutuskan bahawa perkataan 'gender' yang digunakan dalam Perkara 8(2) Perlembagaan Persekutuan bagi tujuan memenuhi obligasi atau pematuhan Malaysia di bawah Konvensyen Penghapusan Segala Bentuk Diskriminasi Terhadap Wanita. Konvensyen CEDAW mempunyai kuasa undang-undang dan mengikat ke atas ahli negara yang telah meratifikasikannya termasuklah Malaysia.

Dalam mentafsirkan Perkara 8(2) Perlembagaan Persekutuan, adalah menjadi kewajipan mahkamah untuk mengambil kira komitmen kerajaan di peringkat antarabangsa. Justeru itu, tidak menjadi halangan untuk mahkamah merujuk kepada Konvensyen CEDAW untuk mentafsir Perkara 8(2) Perlembagaan Persekutuan.

Keputusan kes ini telah menunjukkan usaha Kerajaan Malaysia dalam menggubal atau meminda sesuatu untuk mengelakkan diskriminasi terhadap wanita seperti menambah perkataan 'gender' sebagai suatu jenis diskriminasi dalam Perkara 8(2). Penghakiman di dalam mahkamah juga telah jelas menerima pakai Artikel Konvensyen CEDAW berbanding di dalam kes Beatrice di mana maksud diskriminasi yang ingin dicapai oleh Konvensyen CEDAW gagal diintrepretasikan di dalam mahkamah.

\section{Perlantikan Hakim atau Kadi Wanita di Mahkamah Syariah}

Isu perdebatan berkenaan perlantikan Hakim Syarie Wanita telah berlaku sekitar awal tahun 2000 setelah cadangan berhubung perlantikan wanita sebagai Hakim Syarie telah disuarakan oleh pelbagai pihak.

Hasil perbincangan telah membawa kepada usul untuk melantik hakim wanita di Mahkamah Syariah sebagai suatu tindak balas terhadap isu perundangan yang didakwa mendiskriminasikan wanita (Zaini Nasohah et al., 2015: 62-70). Gesaan supaya dilantik hakim wanita juga terjadi apabila berlaku kelewatan penyelesaian kes akibat kekurangan hakim di Mahkamah Syariah.

Bidangkuasa untuk melantik Hakim Mahkamah Syariah di Malaysia adalah terletak di bawah bidangkuasa negeri-negeri. Peruntukan yang menyatakan perihal tersebut terdapat di dalam Akta atau Enakmen Pentadbiran UndangUndang Islam negeri-negeri. Analisa berdasarkan syarat peruntukan pelantikan hakim di negeri-negeri tidak menunjukkan bahawa seseorang hakim tertakluk kepada suatu jantina tertentu. Peruntukan yang digariskan hanya bersifat umum, iaitu seorang Islam dan warganegara, di samping peruntukan sampingan yang lain. 
Akan tetapi terdapat perbezaan peruntukan pada Enakmen Pentadbiran Undang-Undang Islam Pahang 1991 berbanding negeri-negeri lain, yang mana berkenaan syarat untuk seseorang yang ingin dilantik sebagai Ketua Hakim Syarie dan Hakim Mahkamah Tinggi hendaklah seseorang lelaki Islam.

Justeru itu, penulis bersetuju dengan pendapat-pendapat yang telah diutarakan oleh ahli-ahli akademik dalam mengharuskan pelantikan Hakim Wanita di Mahkamah Syariah di Malaysia seperti pendapat yang menyangkal keistimewaan lelaki berbanding wanita. Menurutnya ayat "alRijāl Qawwāmūna 'ala Nisā", yang dijadikan sebagai salah satu daripada nas yang digunakan untuk menolak wanita untuk dilantik menjadi hakim dan menunjukkan kelebihan yang ada pada lelaki. Ayat ini bukanlah kelebihan yang terpakai secara umum. Menurut beliau lagi, tafsiran-tafsiran yang menunjukkan lelaki mempunyai kelebihan berbanding wanita dari pelbagai aspek tidak melambangkan roh sebenar al-Quran dan berkemungkinan dakwaan yang tidak tepat sama sekali. Hal ini adalah kerana pandangan tersebut dikeluarkan berasaskan keadaan pada ketika itu yang mana kaum wanita tidak ramai yang cerdik dan melibatkan aktiviti sosial di luar rumah (Raihanah Abdullah, n.d.: 117-125).

Berdasarkan pendapat Siti Zalikhah Md Nor, kehakiman Islam di Malaysia hanya bertitik tolak kepada undang-undang diri dan kesalahan ta 'zīr sahaja tanpa melibatkan hukuman hudūd dan qișāṣ. Maka penghakiman tidak memerlukan ijtihad yang berat dan keperluan penghakiman hanya berdasarkan pentarjihan pandangan fuqaha' zaman silam. Bahkan penerimaan perkhidmatan di Mahkamah Syariah adalah majoriti dari kalangan wanita dan wanita pada masa kini bukan sahaja bertindak sebagai seorang saksi bahkan juga memegang profesion sebagai Pendakwa dan Peguam Syarie (Siti Zalikhah Mohd Noor, 2004: 191).

\section{KESIMPULAN}

Secara kesimpulannya, penulis dapat menyimpulkan bahawa Konvensyen CEDAW adalah antara tiga konvensyen yang telah diterima oleh kerajaan Malaysia untuk diadaptasikan di Malaysia. Selain dari Konvensyen CEDAW terdapat dua lagi konvenyen yang diterima oleh Malaysia iaitu Konvensyen Mengenai Hak Kanak-Kanak (CRC) dan Konvensyen Mengenai Hak Orang Kurang Upaya (CRPD). Dalam ketiga-tiga konvensyen yang wujud di Malaysia, hanya Konvensyen CEDAW tidak memperuntukkan undang-undang tertentu yang memberi penjelasan berkenaan matlamat dan pendirian mereka setelah meratifikasikan konvensyen ini di Malaysia seperti Konvensyen CRC memiliki Akta Kanak-Kanak 2001 [Akta 611] dan Konvensyen CRPD 
memiliki Akta Orang Kurang Upaya 2008 sebagai sumber utama kepada penerimaan konvensyen-konvensyen tersebut.

Di samping itu, konsep kesamarataan antara negara Barat dan Islam juga berbeza di dalam konteks tertentu, terutama dalam isu kekeluargaan. Justeru itu, reservasi telah dilakukan untuk menerima masuk konvensyen CEDAW ini di Malaysia. Berdasarkan undang-undang Islam yang digunapakai di Malaysia, perbezaan hukum tertentu tidak membawa kepada diskriminasi terhadap wanita. Hal ini adalah kerana perbezaan tersebut bertujuan untuk penyelarasan sifat biologi dan keupayaan wanita yang berlainan dengan lelaki. Perbezaan tersebut tidak dikatakan sebagai diskriminasi menurut Islam tetapi adalah untuk meletakkan suatu hak kepada tempatnya.

Justeru itu, penerimaan Konvensyen CEDAW dilihat menuntut kepada pihak-pihak khususnya pengamal undang-undang memberi tafsiran yang luas berkenaan tafsiran "diskriminasi" ini sehingga tiada suatu penetapan yang mengikat mereka untuk mengikuti keputusan tersebut. Situasi ini dibuktikan dengan perbezaan tafsiran "diskriminasi" berdasarkan dua kes iaitu kes Beatrice Fernandez dan Noorfadilla Saikin yang telah membawa kepada dua keputusan yang berbeza berdasarkan fakta yang sama iaitu kedua-duanya telah didapati telah dinafikan hak mereka sebagai seorang pekerja akibat telah didapati hamil sewaktu tempoh pekerjaan tersebut. Melalui kes ini, didapati pihak-pihak yang terlibat di dalam proses undang-undang itu sendiri seakanakan tidak mematuhi Konvensyen CEDAW ini.

Wanita tidak dinafikan haknya di mana-mana lapangan di Malaysia tetapi penglibatan wanita masih kurang di lapangan tertentu seperti politik. Hal ini mungkin kesan dari pembudayaan yang diterapkan dari keluarga yang menghalang wanita untuk bersifat berdaya saing dan menyuarakan pendapat mereka dengan lantang dalam khalayak ramai juga terdapat stereotaip di mana wanita perlu mengutamakan kerja-kerja domestik, manakala lelaki perlu keluar mencari rezeki. Pandangan sebegini adalah tidak lagi relevan untuk diamalkan pada zaman ini kerana kedua-dua pihak sama ada lelaki atau wanita terlibat di dalam bidang pekerjaan dan tidak seharusnya seseorang isteri yang sama bekerja seperti suami dibebani secara penuh tugasan domestik ke atasnya. Tanggapan tugasan tertentu menurut gender ini perlu dihapuskan sama sekali bagi memastikan Malaysia mematuhi peruntukan Artikel 2 Konvenyen CEDAW.

Di samping itu, terdapat beberapa undang-undang yang telah digubal dan dipinda untuk memastikan usaha pihak kerajaan bagi mematuhi Konvensyen CEDAW ini. Antara undang-undang yang telah digubal adalah Akta Keganasan Rumah Tangga, pindaan terhadap Akta Penjagaan Kanak-Kanak 1961, Akta 
Pembahagian 1958, Kanun Keseksaan dan lain-lain lagi. Ini adalah usaha yang patut dipuji kerana penggubalan ini menunjukkan kerajaan Malaysia telah berusaha untuk mengubah nasib wanita di Malaysia.

Selain dari itu, terdapat juga dasar-dasar dan usaha tertentu yang telah digubal untuk meningkatkan lagi penglibatan wanita di lapangan masyarakat seperti Dasar Wanita, Penubuhan Gender Focal Point di dalam agensi kerajaan. Akan tetapi usaha-usaha ini dilihat hanya rancak pada peringkat penggubalannya sahaja dan implimentasi perlaksanaannya adalah amat tidak memberangsangkan menurut Pegawai SUHAKAM yang telah ditemu bual untuk mengenalpasti respon beliau terhadap kesan ratifikasi CEDAW ini. ${ }^{25}$

Malahan kerajaan Malaysia gagal untuk mematuhi tarikh penghantaran laporan kepada Jawatankuasa Konvensyen CEDAW yang mana telah berlaku penangguhan selama beberapa kali. Laporan tersebut perlu dihantar kepada Jawatankuasa CEDAW selama 4 tahun sekali. Oleh itu, kegagalan pihak-pihak untuk mematuhi arahan tersebut menunjukkan tiada usaha yang tegas dalam menilai perubahan yang berlaku ke atas wanita di Malaysia.

Di samping itu, kegagalan penghantaran laporan berkala ini dilihat sebagai seolah-olah pihak kerajaan tidak mematuhi peruntukan artikel 18 Konvensyen CEDAW iaitu kewajipan pihak-pihak untuk mengemukakan laporan mengenai perundangan, langkah-langkah kehakiman, pentadbiran atau lain-lain yang telah digunapakai untuk memberi kesan kepada peruntukan CEDAW dan mengenai kemajuan yang dibuat.

Selain dari itu, dari sudut reservasi yang diletakkan oleh Malaysia terhadap beberapa artikel CEDAW telah menjadi isu perdebatan di kalangan pihakpihak yang menuntut untuk pengaplikasian dan pematuhan terhadap semua Artikel di dalam Konvensyen CEDAW ini. Antaranya adalah berhubung Artikel 9(2) berkenaan kewarganegaraan yang mana rata-rata pihak pemerhati seperti SUHAKAM menyatakan bahawa tiada suatu kesan atau masalah yang besar untuk menarik balik reservasi terhadap artikel ini. Hal ini kerana isu hanya berlingkar di dalam aspek prosedur sahaja. Justeru itu, pihak kerajaan perlu menyatakan prosedur-prosedur untuk diikuti bagi mendaftarkan kewarganegaraan bagi pihak wanita yang berkahwin dengan warga asing, setelah itu pihak Jawatankuasa Antarabangsa akan menghormati peruntukan tersebut maka reservasi boleh ditarik balik.

25 Siti Zaihan Zulkarnain (Penolong Setiausaha Bahagian Polisi, Undang-Undang dan Aduan Suruhanjaya Hak Asasi Manusia), dalam temu bual beliau bersama penulis, pada 13 Mei 2015. 
Manakala berhubung Artikel 16 yang berhubung kait dengan kekeluargaan adalah dikatakan bercanggah dengan undang-undang keluarga Islam yang diamalkan bagi orang Islam di Malaysia adalah antara isu sensitif di Malaysia. Banyak pihak yang telah memberi maklumbalas berkenaan artikel ini sama ada dari pihak pengamal undang-undang Islam dan pihak-pihak NGO.

Pihak-pihak tersebut berbeza hujah iaitu bersetuju untuk menerima reservasi dan suatu pihak lagi berharap supaya reservasi terhadap artikel ini ditarik balik. Sehubungan dengan itu, penulis berpandangan bahawa artikel ini perlu diteliti dan pemahaman perlu diberikan kepada pihak-pihak yang menentang secara tegas kerana konsep yang dibawa oleh Islam terutamanya berkenaan isu perwalian yang mana tidak menunjukkan bahawa berlaku diskriminasi terhadap wanita kerana terdapat matlamat yang tertentu ingin dicapai oleh hukum Islam seperti supaya anak perempuan tersebut memilih pasangan hidup yang benar dan pemahaman konsep sebenar berkenaan hukum Islam perlu diberi penjelasan dengan cermat kepada golongan-golongan yang menolaknya kerana hukum Islam walaupun berbeza pendekatan antara lelaki dan wanita tapi perbezaan itu menghasilkan suatu kesan seimbang antara duadua jantina.

Selain itu, antara alasan utama yang dikemukakan untuk meletakkan reservasi atas Artikel tertentu adalah kerana terikat dengan budaya, adat atau tradisi. Dalam konteks majoriti, negara-negara ahli menyatakan bahawa melakukan perubahan adalah sukar dan mengambil masa dalam berhadapan dengan tradisi tersebut. Dalam konteks minoriti, negara-negara ahli menyatakan bahawa sikap tidak campur tangan dan kekurangan pembaharuan adalah kerana menghormati masyarakat. Akibat daripada ini, hak-hak wanita telah tidak diendahkan bagi memihak kepada tanggapan kabur berkenaan "kebudayaan" tersebut.

Dalam kebanyakan kes, apa yang menjadi sebab di sebalik keengganan negara-negara ahli untuk bertindak adalah disebabkan pertimbangan politik dan bukannya disebabkan prinsip-prinsip agama dan sebenarnya wujud ruang untuk mengiktiraf hak-hak wanita dalam budaya dan tradisi. Ia adalah penting untuk menyedari bahawa budaya dan amalan Islam dan kaum Muslim adalah tidak terpencil tetapi wujud konteks yang mana terdapat pelbagai budaya dan pelbagai tuntutan hak dari kumpulan sosial yang berbeza. Islam mengintepretasikan sesuatu adat itu berbeza mengikut adat yang berlaku dalam sesebuah negara.

Walau bagaimanapun, hakikat bahawa adat adalah dinamik maka konsep dan prinsip yang menyatakan bahawa fiqh boleh berubah mengikut realiti perubahan semasa dan tempat serta boleh memberi peluang kepada perubahan 
dalam undang-undang dan amalan ke arah memenuhi tuntutan hak yang lebih besar (Sisters in Islam, 2011: 97).

Rangka Kerja Musāwāh telah berhujah bahawa pendekatan berbilang (multi-pronged approach) adalah cara yang paling berkesan untuk memastikan kesaksamaan dan keadilan. Ia adalah penting untuk melihat agama, standard hak asasi manusia, jaminan perlembagaan dan hidup realiti secara sama dan bukannya berasingan. Ia adalah tidak boleh diterima untuk menolak prinsip Konvensyen CEDAW berdasarkan pemahaman patriarki terhadap ayat alQuran atau untuk mengabaikan kesan-kesan buruk akibat daripada suatu fenomena sosial moden dengan mengunakan alasan untuk menghormati amalan tradisional. Setiap orang perlu mendekati isu ini secara holistik, mengintegrasikan hak asasi manusia dan prinsip-prinsip Islam dalam satu proses yang dinamik dan sentiasa berkembang.

Hasil dapatan penulis, telah mendapati bahawa Konvensyen CEDAW ini mula disedari oleh semua pihak dan langkah-langkah tertentu telah diambil tetapi implimentasi ke atas langkah yang dirangka berada di tahap yang mengecewakan. Hal ini kerana isu tersebut hanya dilihat rancak dibahaskan apabila sesuatu isu menjadi tumpuan orang awam dan setelah isu tersebut reda keadaan kembali seperti asal iaitu setiap orang mula merendah-rendahkan golongan wanita dengan streotaip tertentu bahkan dalam suatu sidang parlimen juga pernah didapati berlaku ucapan yang berbaur seksis terhadap wanita, ini adalah suatu yang tidak patut terjadi dalam kerangka usaha Malaysia sebagai ahli pada Konvensyen CEDAW. Justeru itu, setiap pihak dari kementerian, pengkritik, pengamal undang-undang bahkan orang awam perlu mendapatkan kesedaran yang mampan bagi mencapai maksud yang diinginkan oleh Konvensyen CEDAW dan pengharmoniannya dengan undang-undang Islam.

\section{RUJUKAN}

Abdulssalam, Ahmad Shehu (2006). "Gender and Sexuality: An Islamic Perspectives," Jurnal Alam dan Tamadun Melayu, Sari, vol. 24.

Abu Abdillah Muhammad bin Ismail Al-Bukhari (2009). Shahih Bukhari: Terjemahan Hadis. Kuala Lumpur: Klang Book Centre.

Anuradha Rao and The International Women's Rights Action Watch (2008). "Domestic Application of the Convention on the Elimination of All Forms of Discrimination: Potential and Actuality," WLUML DOSSIER, vol. 29. 
Committee on the Elimination of Discrimination Against Women (2006). Concluding Comments of the Committee on the Elimination of Discrimination Against Women: Malaysia Combine Initial and Second Periodic Report. Malaysia: Kementerian Pembangunan Wanita, Keluarga dan Masyarakat, Malaysia.

Maizatul Azila Chee Din, Hawa Rahmat \& Rohaidah Mashudi (2011). "Pregnancy and Discrimation: Effect of the Case Beatrice A/P Fernandez v. Sistem Penerbangan Malaysia and Others," International Journal of the Computer, the Internet and Management, vol. 19, no. 2.

Mohd Anuar Ramli (2010). "Bias Gender dalam Ajaran Muslim: Antara Ajaran Islam dan Budaya Tempatan," Jurnal Fiqh, vol. 1, no. 7.

Mohd Anuar Ramli (2012). “Analisis Gender dalam Hukum Islam,” Jurnal Fiqh, vol. 9.

Mohd Ridzuan Awang (2008). "Isu-Isu Keadilan dalam Pengagihan Harta Pusaka," dalam Isu Fiqh dan Persoalan Semasa, ed. Zamzuri Zakaria, Zaini Nasohah. Anwar Fakhri Omar. Bangi: Pusat Penerbitan dan Percetakan Universiti Kebangsaan Malaysia.

Muhammad al-Sayyid Sabiq (2008). Fiqh Sunnah. Kuala Lumpur: al-Hidayah Publication.

Nik Noraini Nik Badlishah (2003). Islamic Family Law and Justice for Muslim Women. Kuala Lumpur: Perpustakaan Negara Malaysia Cataloguing in Publication Data.

Noor Aziah Mohd Awal (2003). "Women and Law," dalam Women in Malaysia Breaking Boundaries, ed. A. H. Roziah Omar. Seri Kembangan: Utusan Publications and Distributors Sdn. Bhd.

Raihanah Abdullah (n.d.). Surah al-Nisa', Ayat 34: Suatu Analisa Awalan. Kuala Lumpur: Universiti Malaya.

Șaḥị̣ al-Bukhārī (n.d.), Sharh Fath al-Bārī. Qāhirah: Dār al-Salām, no. hadis 4425, Kitāb al-Maghāzi "Bab: Kitāb al-Nabiyyu 'alayh wa sallam illa Qusra wa Qaysir".

Sara Charlesworth (2008). "Legislation and Mechnism for Promoting Gender Equality: The Australian Experience," Women Living Under Muslim Law Dossier, vol. 29.

Siti Zalikhah Mohd Noor (2004). "Hakim Wanita: Satu Paradoks," Jurnal Hukum, vol. 23, no. 2.

Su'ad Suthi Nasr Salman (n.d.). Fātāwā al-Nisā' li Asbāb al-Fadilah Yūsuf al-Qaraḍ̄wī̄. Beirūt: Mu'assasāh al-Risālah. 
Suruhanjaya Hak Asasi Manusia Malaysia (2009). "Suruhanjaya Hak Asasi Manusia Malaysia Konvensyen Mengenai Penghapusan Segala Bentuk Diskriminasi Terhadap Wanita," (Kertas Kerja Pembentangan di Konvensyen Mengenai Penghapusan Segala Bentuk Diskriminasi Terhadap Wanita, Kuala Lumpur).

Suruhanjaya Hak Asasi Manusia Malaysia (2015). Laporan Perbincangan Meja Bulat Mengenai Reservasi Terhadap Konvensyen CEDAW, CRC \& CRPD (pp. 13). Kuala Lumpur: Suruhanjaya Hak Asasi Manusia Malaysia.

Syaikh Abdul Rahman al-Juzairi (2011). Fiqh 4 Mazhab (Juzuk 4 \& 5). Johor Bahru: Perniagaan Jahabersa.

UN Women East and Southeast Asia Region (2016). "The Principle of CEDAW," UN Women East and Southeast Asia Region United Nations Entity for Gender Equality and the Empowerment of Women Retrieved 14 March 2016, from http://asiapacific.unwomen.org/en/focus-areas/ cedaw-human-rights

Zaini Nasohah, Fatimah Majemi, Zuliza Mohd Kusrin, Ahmad Muhammad Husni \& Mohd Al-Adib Samurie (2015). "Analisis Literatur Isu Perlantikan Hakim Syarie Wanita di Malaysia," International Journal of Islamic and Civilaztions Studies, vol. 3, no. 1.

Zuliza Mohd Kusrin \& Muhammad Hazuman Zulkifli (n.d). Konsep Kesamarataan Gender dalam Perkahwinan menurut CEDAW dan Akta Undang-Undang Keluarga Islam (Wilayah-wilayah Persekutuan) 1984. Bangi: Universiti Kebangsaan Malaysia.

\section{Senarai Statut}

Akta Undang-Undang Keluarga Islam (Wilayah-wilayah Persekutuan) 1984.

\section{Senarai Kes}

Beatrice A/P Fernandez v. Sistem Penerbangan Malaysia \& Anor [2004] 4 MLJ 466.

Beatrice A/P Fernandez v. Sistem Penerbangan Malaysia \& Anor [2004] 3 MLJ 681.

Noorfadilla Ahmad Saikin v. Chayed Basirun [2012] 1 MLJ. 


\section{Senarai Temu bual}

Siti Zaihan Zulkarnain (Penolong Setiausaha Bahagian Polisi, UndangUndang dan Aduan Suruhanjaya Hak Asasi Manusia), dalam temu bual beliau bersama penulis, pada 13 Mei 2015. 
Journal of Shariah Law Research (JSLR) 